\title{
Nutritional Evaluation of Sago of Gebang Tree (Corypha utan Lamk) from Different Locations in West Timor - Indonesia for Broilers
}

\author{
C. L. Nalle*, Helda, B. Masus, \& J. Malo \\ Department of Animal Husbandry, Kupang State Agriculture Polytechnic \\ Jalan Prof. Herman Yohanes, Kupang 85228, Nusa Tenggara Timur, Indonesia \\ *Corresponding author: nallecatootjie@gmail.com \\ (Received 22-05-2020; Revised 06-07-2020; Accepted 03-08-2020)
}

\begin{abstract}
Two experiments were conducted to evaluate the nutritional value of sago from different locations in West Timor, Indonesia for broilers. Experiment I aimed at determining the apparent metabolizable energy (AME) and nutrient digestibility of sago from different locations. A total of 120 broilers (unsexed, age $21 \mathrm{~d}$ ) were randomly distributed to 24 metabolic cages (5 birds/cage). The experimental design was a completely randomized design (CRD) consisting of 6 treatments and 4 replications. The experimental diets were a basal diet (maize-soy) and 5 treatment diets which were a mixture of basal ration $(\mathbf{7 5} \%)$ and sago $(25 \%)$ from different locations. Experiment II was about performance trials. Two different basal diets were formulated, supplemented with synbiotics and fed to 200 birds (unsexed, $10 \mathrm{birds} /$ pen). The experimental design was a $2 \times 2$ factorial CRD. With the exception of phytate and phenol contents, the results showed that the location affected $(p<0.05$ to 0.01$)$ the contents of dry matter, crude protein, and crude fiber, tannins, NDF, ADF, flavonoids, AME/n, and starch digestibility of sago. The location did not affect $(p>0.05)$ ash, crude fat, starch, $C a, P$, and gross energy contents of sago. Basal diets affected ( $\mathrm{p}<0.05$ to 0.001 ) all performance traits. Except for BWG, synbiotics did not affect $(p>0.05)$ the performance of the birds. In conclusion, the nutrient composition and digestibility of sago are affected by locations. Sago is rich in starch and high in AME values, but poor sources of calcium, phosphor, and protein. Sago contains fiber, tannin, phytate, flavonoids, and phenol. Sago diets improved the performance of broilers. Synbiotics did not improve the performance of birds.
\end{abstract}

Keywords: AME; anti-nutrient; nutrient digestibility; performance; sago; synbiotics

\section{INTRODUCTION}

Feed is the largest cost component of poultry production, totaling $60 \%$ to $70 \%$ of the total cost. Efforts should be made to reduce feed costs and to improve the profit for animal farmers. Methods that can be considered in order to reduce feed costs are enzyme supplementation (Raza et al., 2019; Wealleans et al., 2017; Tahir et al., 2015; Spring, 2013), formulation of the diets using digestible amino acids rather than total amino acids (Lu et al., 2020; Ravindran et al., 2017; Kidd \& Tillman, 2016; Bryden \& Li, 2010), and utilization of alternative feedstuffs (Olukosi et al., 2019, Alqaisi et al., 2017; Swain et al., 2014; Nalle et al., 2011, 2012). However, when considering alternative feed ingredients, the quality, availability, and price of the ingredients need to be taken into account.

Sago, an edible starch obtained from the pith of the gebang tree, has the potential to be used as an alternative feed ingredient in poultry diets. Corypha utan Lamk (gebang tree) is one of the most common palm species that produce sago. This species is found abundantly in the continents of Australia (Queensland and Northern Territory) and Asia (Indonesia, India, Malaysia,
Philippines, Papua New Guinea, Bangladesh, Thailand, and Myanmar) (Eagleton, 2016). In Indonesia, the gebang tree can be found in Java, Kalimantan, Sumatera, Maluku, Sulawesi, and Timor Island. In West Timor, East Nusa Tenggara Province (Indonesia), the gebang trees grow wild in grazing areas (savanna), shrublands, and forests. Except for protected forest areas, gebang trees found in grazing areas (savanna), shrublands, and unprotected forests are allowed to be cut down and utilized by local people. Almost all parts of the tree including the trunk, leaves, and fruit, are useful for human and animal needs (Eagleton, 2016; Naiola \& Nurhidayaf, 2009). The leaves are usually used for weaving mats or as a roofing material found in traditional houses. The pith of the trunk is used for animal feed, both in wet (chopping) and dry (ground) forms. In West Timor, the pith of the gebang's trunk is known as "putak", while people in North Sulawesi know it as "gumbar" (Eagleton, 2016).

The height of a mature gebang tree is between 20 to $30 \mathrm{~m}$ and the average stem diameter is $60 \mathrm{~cm}$ (Eagleton, 2016; Prasetyo et al., 2008). One gebang tree can produce around 8 to $10 \operatorname{logs}$ with a length of $70 \mathrm{~cm}$ and a diameter of $60 \mathrm{~cm}$ (Prasetyo et al., 2008). The thick bark 
of the stems is then removed to reveal the pith. The pith is normally cut into 8 to 10 parts. The weight of each part of the pith varies from 8.08 to $36.32 \mathrm{~kg}$, with an average of $14.08 \mathrm{~kg}$. Based on this information, it can be estimated that a single gebang tree can produce 1140.5 $\mathrm{kg}$ pith (wet form). Furthermore, it can be said that $1 \mathrm{~kg}$ of pith (in the wet form) produces about $0.438 \mathrm{~kg}$ of sago (dry and ground form), $0.172 \mathrm{~kg}$ of hard and undigested fiber, and the remaining, $0.391 \mathrm{~kg}$, is evaporated water. Therefore, a gebang tree can produce $499.54 \mathrm{~kg}$ (as is basis) of sago that can be used as a poultry feed.

Published data about the nutritional value of sago as a poultry feed is very limited (Nalle et al., 2017, 2019a). Nalle et al. $(2017,2019$ a) report that sago is rich in nitrogen-free extract $(73.68 \%)$, but poor in crude protein $(2.15 \%$ to $3.66 \%)$. The authors also reported that the neutral detergent fiber (NDF) content of sago ranged from $18.87 \%$ to $26.75 \%$ compared with $36.53 \%$ of yellow maize. The apparent metabolizable energy values (AMEn) of sago were reported to be $10.67 \mathrm{MJ} / \mathrm{kg}$ DM (Nalle et al., 2017), but this value was obtained from only one sago sample. The authors also reported that sago could be included in broiler starter diets up to $20 \%$ without any detrimental effects. However, the higher inclusion level of sago has not been evaluated either in starter broilers or in growing broilers.

The variation in the nutrient content of sago as reported by previous studies (Nalle et al., 2017; 2019a) was probably due to the difference in the environmental factors. However, published data about the effect of the environmental factors on the nutritional value of sago (putak) is not available. The NDF content of sago seems to be lower than the NDF content of yellow maize; however, the texture of sago fiber is harder than that of corn. Previous studies (Ayres et al., 2019; Yaghobfar \& Kalantar, 2017; Bao et al., 2013) showed that feeding diets containing high fiber would increase the intestinal viscosity, the pathogenic microbial population, and reduce the pancreatic enzyme activity and the nutrient digestibility. The increase of the pathogenic microbial population will negatively affect gut health and growth performance. The improvement of the nutritional value of diets containing sago through the addition of different types of feed additives such as synbiotics, prebiotics, and probiotics are limited.

Based on all of this information, the present study was conducted to evaluate the effect of location on the nutritional value of sago for broilers. The variation in soil fertilities and other environmental factors in different locations may affect the nutrient composition of sago. The improvement of the nutritional value of the sago diet by the addition of a commercial synbiotics was also conducted in the performance trial. The synbiotics product (Probio FM ${ }^{\text {plus }}$ ) used in the present study contains prebiotics (obtained from putak meal mixed with liquid sugar from lontar tree) and probiotics (Lactobacillus spp bacteria) which were expected to improve the gut health and the growth performance of broilers fed diets containing sago.

\section{MATERIALS AND METHODS}

\section{Animal Ethics}

The procedures of the present study were reviewed and approved by the Animal Ethics Committee of the Faculty of Veterinary Medicine, University of Nusa Cendana Kupang-Indonesia, with Ethical Clearance Number KEH/FKH/NPEH/012/2019 on May $21^{\text {st }} 2019$.

\section{Ingredients}

The sago was made from the pith stems (or putak as it is locally known) of gebang trees (Corypha utan Lamk) which were obtained from five different locations in West Timor - Indonesia, namely Naibonat 1, Naibonat 2, Lili, Bipolo, and Pariti. The process of producing sago from the pith of a gebang tree (a) was conducted by the following steps (Figure 1): 1) The stem of the gebang tree was cut into 8-10 logs (b), 2) the thick bark of the tree trunk was then removed to get the pith (wet form, c), 3) the round pith stems were cut into several parts, weighing 12-18 kg each (d), 4) then they were chopped into small pieces (e) before being ground with a hammer mill (3 mm screen size, f). 5) The ground pith was then sun-dried for two days (g), and sieved (2 mm screen size, h) to remove the hard and undigested fiber (i). At this point, the final product, known as sago (putak meal, j) was ready to be used in the experiment.

\section{Experiment I: Nutritional evaluation of sago from dif- ferent locations in West Timor Indonesia}

Assay diets. A maize-soybean meal basal diet (in mash form) was formulated to contain $20 \%$ crude protein (Table 1). Five assay diets (in mash form) were then formulated by substituting the sago sample from different locations at $250 \mathrm{~g} / \mathrm{kg}$ in the basal diet.

Birds and housing. A total of 300 one-day old broiler chicks (unsexed, Cobb strain) obtained from a local commercial hatchery were reared in a floor pen for 21 days. The chicks were fed commercial feed containing 23\% crude protein from day 1 to day 21. Drinking water was available on an ad libitum basis. A gasolec, as a brooder, was placed in the middle of the floor pen to warm the chicks in the first week. The temperature and relative humidity were monitored using a thermo-hygrometer. On the $21^{\text {st }}$ day, a total of 120 birds, with nearly the same body weight, were randomly distributed into 24 metabolic cages ( 5 birds/pen) for determination of apparent metabolizable energy (AME) and nutrient digestibility. On days 21 to 28 , the birds were fed commercial feed containing $20 \%$ crude protein.

Experimental design. The experiment was designed using a completely randomized design with six treatments and four replications. Therefore, there were 24 experimental units (cages) with each experimental unit consisting of five birds. The experimental diets used were: $\mathrm{T} 0=$ Basal diet based on maize-soybean meal; $\mathrm{T} 1=$ $75 \%$ Basal diet based on maize-soybean meal $+25 \%$ 


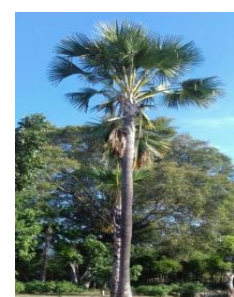

a. Gebang palm (Corypha utan Lamk)

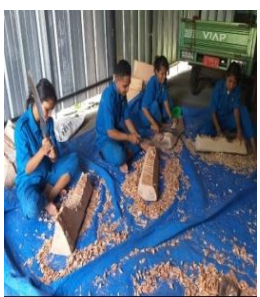

e. Pith chipping

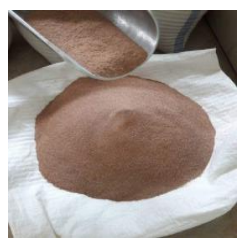

i. Sago obtained after sieving

process

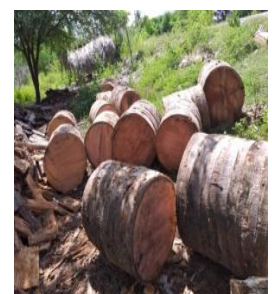

b. Logs of gebang palm

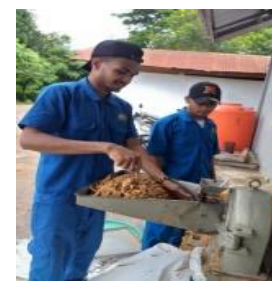

f. Pith grinding

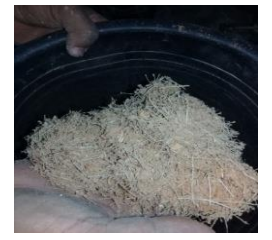

j. Fiber removed through sieving process

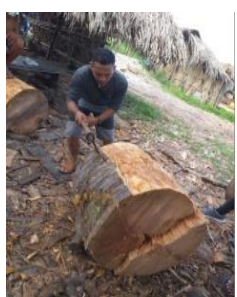

c. Thick bark removing to produce pith

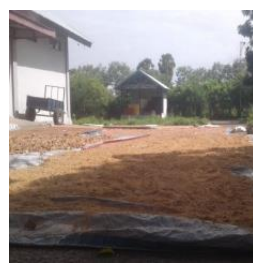

g. Sun drying

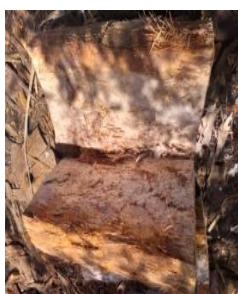

d. Pith of gebang palm

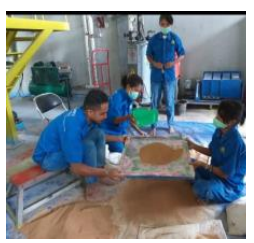

h. Sieving process to remove fiber

Figure 1. The process of producing sago from the pith of a gebang tree

Table 1. Basal diet composition (Experiment 1)

\begin{tabular}{lc}
\hline \multicolumn{1}{c}{ Feed ingredients } & \% (as is) \\
\hline Yellow maize, $8.5 \%$ CP & 59.09 \\
Soybean meal, 44\% CP & 35.18 \\
Vegetable oil & 2.00 \\
Limestone Feed Grade (powder) & 0.78 \\
Dicalcium phosphate Ca22/P18 & 2.17 \\
Salt & 0.25 \\
Sodium bicarbonate & 0.23 \\
Vitamin and Mineral Premix* & 0.30 \\
Total & 100.00 \\
Nutrient composition (calculated, as fed) & \\
$\quad$ Apparent metabolizable energy $(\mathrm{kcal} / \mathrm{kg})$ & 12.32 \\
Crude protein $(\mathrm{g} / \mathrm{kg})$ & 205 \\
Crude fiber $(\mathrm{g} / \mathrm{kg})$ & 36.44 \\
Lysine $(\mathrm{g} / \mathrm{kg})$ & 11.0 \\
Met + Cyst $(\mathrm{g} / \mathrm{kg})$ & 6.6 \\
Ca $(\mathrm{g} / \mathrm{kg})$ & 8.9 \\
Av P $(\mathrm{g} / \mathrm{kg})$ & 6.8 \\
\hline
\end{tabular}

Note: ${ }^{*}$ Top Mix $=$ Every $10 \mathrm{~kg}$ contain: $12.000 .000 \mathrm{IU}$ vitamin A; 2.000 .000 IU vitamin D; 8.000 IU vitamin E; vitamin K3 2.000 mg; vitamin B1 $2000 \mathrm{~m}$; vitamin B2 $5.000 \mathrm{mg}$; vitamin B12 $12.000 .000 \mu$ g; vitamin C $25.000 \mathrm{mg}$; Calcium-D-pantothenate $6000 \mathrm{mg}$; choline chloride $10.000 \mathrm{mg}$; niacin $40.000 \mathrm{mg}$; methionine $30.000 \mathrm{mg}$; lysine 30.000 mg; mangan 120.000 mg; Fe 20.000 mg; iodine 200 mg; zinc 100.000 $\mathrm{mg}$; cobalt $200 \mathrm{mg}$; copper $4.000 \mathrm{mg}$; santoquin (antioxidant) $10.000 \mathrm{mg}$. sago from Naibonat $1 ; \mathrm{T} 2=75 \%$ Basal diet based on maize-soybean meal $+25 \%$ sago from Naibonat 2; T3= $75 \%$ Basal diet based on maize-soybean meal $+25 \%$ sago from Pariti; T4= 75\% Basal diet based on maize-soybean meal $+25 \%$ sago from Bipolo; and $\mathrm{T} 5=75 \%$ Basal diet based on maize-soybean meal $+25 \%$ sago from Lili.

Excreta collection. The classical total excreta collection method was used in determining metabolizable energy and fecal nutrient digestibility (Nalle et al., 2010). The introduction of experimental diets (in mash form) was started on the $28^{\text {th }}$ day. Feed intake and excreta output were measured and recorded quantitatively per cage from days 32 to 35 . Then, the excreta from each cage were pooled, mixed, sub-sampled, and oven-dried (at $60^{\circ} \mathrm{C}$ ). The dried excreta samples, basal diets, assay diets, and sago samples were ground using a sample mill (0.5 mm screen size), packed, and sent to the laboratory for analysis. The dried excreta, basal diets, assay diets, and sago samples were analyzed for dry matter, gross energy, nitrogen, starch, and amino acid contents.

Chemical analysis. The dry matter content was determined by using AOAC method no. 930.15 (AOAC, 2005). The nitrogen content was analyzed using AOAC 2001.1 (AOAC, 2005) in three different steps, which were digestion (BÜTCHI SpeedDigester K-439), distillation (BÜTCHI Distillation Unit K-355), and titration. 
The AOAC 942.5 (Van Soest Method, AOAC, 2005) was used to determine NDF and ADF contents. The acid detergent fiber (ADF) analysis was conducted as follows: The sample was added with ADF solution and digested, filtered (with sintered glass funnel and a vacuum), rinsed with acetone, then dried at $105^{\circ} \mathrm{C}$ in an oven overnight. Whereas, the analytical procedure of the neutral detergent fiber (NDF) was as follows: weighed approximately 0.45 to $0.55 \mathrm{~g}$ of the sample, added with NDF solution, digested, filtered (with sintered glass funnel and a vacuum), rinsed with acetone, oven dried $\left(105{ }^{\circ} \mathrm{C}\right)$ overnight, cooled in a desiccator for about 30 minutes and weighed.

The starch content of sago was analyzed using the titration method (SNI 01-2891-1992). The starch analysis procedure was conducted as follows: weighed approximately $5 \mathrm{~g}$ of the sample into the $500 \mathrm{~mL}$ Erlenmeyer, then added $200 \mathrm{~mL}$ of $3 \% \mathrm{HCl}$ solution, and boiled for 3 hours. Cooled and neutralized with $30 \% \mathrm{NaOH}$ solution, and added $3 \% \mathrm{CaCO}_{3}$ so that the solution was slightly acidic. The contents were transferred into a 500 $\mathrm{mL}$ volumetric flask and squeezed them, and filtered. As much as $10 \mathrm{~mL}$ of filtrate was pipette into the 500 $\mathrm{mL}$ Erlenmeyer, and $25 \mathrm{~mL}$ of Luff Schoorl solution was added with a pipette. A few boiling bolts and $15 \mathrm{~mL}$ of distilled water were added to the mixture. The mixture was heated on a steady flame to bring the solution to a boil within 3 minutes; this was then simmered for exactly 10 minutes. This solution was then quickly cooled in a tub of ice. After chilling, slowly add $15 \mathrm{~mL}$ of KI $20 \%$ solution and $25 \mathrm{~mL}$ of $25 \% \mathrm{H}_{2} \mathrm{SO}_{4}$. Then, immediately titrate with $0.1 \mathrm{~N}$ sodium thiosulphate solution. A blank was also analyzed at the same time.

Automatic Bomb Calorimeter (IKA C2000) was used to measure the gross energy level. The gross energy analysis was conducted as follows: One gram of the ground sample was placed in a dish. As much as $10 \mathrm{~cm}$ threads were tied to the fuser wire and positioned under the sample. The heat bomb was closed and it was put in the bomb cylinder. Oxygen $(\mathrm{O} 2)$ was added to the bomb at a flow rate of approximately 30 ATM / BAR. Two liter of distilled water was added into the bucket. The bomb was put in the bucket, the ignition fire was connected, then the drive ring was attached and stirrer turned on. The digital temperature machine was turned on and left for 5 minutes for the temperature to stabilize. The initial temperature was recorded and then, the bombing was carried out by pressing the bomb button and waited for about 5 to 10 seconds for the temperature to rise. The final temperature reading was recorded when the temperature rises and then the drops.

The calcium $(\mathrm{Ca})$ and phosphor $(\mathrm{P})$ content was analyzed using an Atomic Absorption Spectrophotometer (AAS) and Spectrophotometer, respectively. The analytical procedure of $\mathrm{Ca}$ and $\mathrm{P}$ was as follows: the sample was weighed and then ignited $\left(550{ }^{\circ} \mathrm{C}\right)$ for 3 hours, digested using acid solution, dissolved into a measuring flask, pipetted, and measured with AAS at a wavelength of $422.7 \mathrm{~nm}$ for Ca content; while, for $\mathrm{P}$ content, the measurement was conducted with a spectrophotometer at a wavelength $400 \mathrm{~nm}$.
The amino acid content was determined using High Performance Liquid Chromatography (HPLC, ICI Instrument/Shimadzu SCL-10A/Shimadzu CBM 20A) as described by Nalle et al. (2019b). The procedure was as follows: The samples were hydrolyzed with $6 \mathrm{~N} \mathrm{HCl}$ (containing phenol) for $24 \mathrm{~h}$ at $110 \pm 2{ }^{\circ} \mathrm{C}$ in glass tubes sealed under vacuum. Amino acids were detected on a Waters ion- exchange HPLC system and the chromatograms were integrated using dedicated software (Millennium, Version 3.05.01, Waters, Millipore, Milford, MA) with the amino acids identified and quantified using a standard amino acid mixture. The HPLC system consisted of an ion-exchange column, two 510 pumps, water 715 ultraWISP sample processor, a column heater, a post column reaction coil heater, a ninhydrin pump and a dual-wavelength detector. Amino acids were eluted by a gradient of $\mathrm{pH} 3.3$ sodium citrate eluent to pH 9.8 sodium borate eluent at a flow rate of $0.4 \mathrm{~mL} / \mathrm{min}$ and a column temperature of $60{ }^{\circ} \mathrm{C}$. Cystein and methionine were analyzed as cysteic acid and methionine sulphone, respectively, by oxidation with performic acid for $16 \mathrm{~h}$ at $0{ }^{\circ} \mathrm{C}$ and neutralization with hydrobromic acid before hydrolysis.

The content of phytic acid was determined using the spectrophotometer method (Haug et al., 1983). The ground sample was extracted with $0.2 \mathrm{~N} \mathrm{HCl}$. As much as $0.5 \mathrm{~mL}$ of the sample extract ( 3 to $30 \mu \mathrm{g} \mathrm{mL}-1$ phytate phosphorus) was pipetted into a test tube fitted with a ground-glass stopper. Then, $1 \mathrm{~mL}$ of ferric solution was added into the tube and with the stopper fixed to the test tube with a clip. The mixture was then heated in a boiling water bath for 30 minutes. It was ensured that the tube remained well stoppered for the first five minutes. Then, the tube was cooled in ice water for 15 minutes and then allowed to adjust to room temperature. The content of the tube was then homogenized and centrifuged for 30 minutes at $3000 \mathrm{~g}$. As much as $1 \mathrm{~mL}$ of the supernatant was transferred into another test tube and $1.5 \mathrm{~mL}$ of 2.2-bipyridine solution was added. The absorbance measurement was carried out at $519 \mathrm{~nm}$ against distilled water.

Total tannins were determined by Folin-Ciocalteu method according to Makkar (2003). A sample of up to $0.2 \mathrm{~g}$ was extracted in $10 \mathrm{~mL}$ aqueous acetone for 20 minutes in an ultrasonic water bath. Then, as much as $0.5 \mathrm{~mL}$ of sample extract was pipetted into a test tube and $0.25 \mathrm{~mL}$ of Folin-Ciocalteu reagent and $1.25 \mathrm{~mL}$ of $20 \%$ sodium carbonate was added. The mixture was then homogenized with a vortex mixer and the solution stood for 40 minutes. Absorbance measurement was conducted at $725 \mathrm{~nm}$. Next, a total of $100 \mathrm{mg}$ of polyvinylpolypyrrolidone (PVPP) was weighed and added with $1 \mathrm{~mL}$ of tannin extract and $1 \mathrm{~mL}$ of distilled water. The mixture was then stored in a room with a temperature of $4^{\circ} \mathrm{C}$ for 15 minutes. The mixture was then centrifuged to separate the supernatant. As much as $0.5 \mathrm{~mL}$ of supernatant was transferred into another test tube, and 0.25 of Folin-Ciocalteu reagent and $1.25 \mathrm{~mL}$ of $20 \%$ sodium carbonate were added. The mixture was mixed with a vortex mixer and left for 40 minutes. Absorbance measurement was carried out at $725 \mathrm{~nm}$. Next, as much as $0 \mathrm{~mL}, 0.02 \mathrm{~mL}, 0.04 \mathrm{~mL}, 0.06 \mathrm{~mL}, 0.08 \mathrm{~mL}$, and 0.1 
$\mathrm{mL}$ of diluted tannic acid standards were pipetted into the test tubes and distilled water was added to reach $0.5 \mathrm{~mL}$ volume. The solution was then had $0.25 \mathrm{~mL}$ of Folin-Ciocalteu reagent and 1.25 of sodium carbonate was added. The mixture was then homogenized using a vortex mixer and left for 40 minutes. Absorbance measurement was conducted at $725 \mathrm{~nm}$.

Total phenols were determined by the FolinCiocalteu Method (Makkar, 2003). A total of $100 \mathrm{mg}$ of extract was dissolved in $10 \mathrm{~mL}$ of distilled water to obtain a concentration of $10 \mathrm{mg} / \mathrm{mL}$. Then, $1 \mathrm{~mL}$ of extract was diluted with distilled water up to $10 \mathrm{~mL}$. Next, 0.2 $\mathrm{mL}$ of extract was pipetted into a test tube and $15.8 \mathrm{~mL}$ of distilled water and $1 \mathrm{~mL}$ of Folin-Ciocalteu reagent were added. The solution was left for 8 minutes, then 3 $\mathrm{mL}$ of $10 \% \mathrm{Na}_{2} \mathrm{CO}_{3}$ was added The mixture was left for 2 hours at room temperature. The absorption was measured with a UV-Vis spectrophotometer at a maximum absorption wavelength of $765 \mathrm{~nm}$. The replications were carried out so that the phenol content obtained was as an equivalent $\mathrm{mg}$ of gallic acid/g of the fresh sample.

The spectrophotometer method was used to determine the content total flavonoid. Flavonoid content was assayed according to Kim et al. (2003). A total of $10 \mathrm{mg}$ of extract was dissolved in $10 \mathrm{~mL}$ of distilled water. Then, as much as $5 \mathrm{~mL}$ of the extract solution was pipetted and $0.3 \mathrm{~mL}$ of $5 \% \mathrm{NaNO}_{2}$ was added. In the next step, the extract mixture was added to $0.3 \mathrm{~mL}$ of $10 \% \mathrm{AlCl}_{3}$ which was dissolved with methanol and incubated at room temperature for 5 minutes. After incubation, $2 \mathrm{~mL}$ of $1 \mathrm{M} \mathrm{NaOH}$ was added and the volume was made up to $10 \mathrm{~mL}$ with distilled water. Absorbance measurements were carried out at a wavelength of $510 \mathrm{~nm}$. Measurements were made three times and the determination of total flavonoids was expressed in catechin equivalent $(\mathrm{CE})(\mathrm{mg} / \mathrm{g})$.

Calculations. The calculation of apparent metabolizable energy (AME) values used the following formulas (Nalle et al., 2010):

$\operatorname{AME}_{\text {diet }}(\mathrm{MJ} / \mathrm{kg})=\left[\left(\right.\right.$ Feed intake $\left.x \mathrm{GE}_{\text {diet }}\right)-($ Excreta output $\left.x \mathrm{GE}_{\text {excreta }}\right)$ ] / Feed intake

$\mathrm{AME}_{\text {sago }}(\mathrm{MJ} / \mathrm{kg})=[\mathrm{AME}$ of sago diet $-(\mathrm{AME}$ basal diet $\mathrm{x}$ $0.75)] / 0.25$

Correction for zero nitrogen retention was made using a factor of $36.54 \mathrm{~kJ}$ per gram nitrogen retained in the body (Hill \& Anderson, 1958).

The total tract nutrient digestibility coefficient was calculated as shown below (McDonald et al., 2002):

Nutrient digestibility coefficient ${ }_{\text {diet }}=$

[(Feed intake $x$ Diet nutrient) $\times$ (Excreta output $\times$ Excreta nutrient)] / (Feed intake $x$ Diet nutrient)

The calculation of amino acid digestibility values used the following formulas (Nalle et al., 2010):

The total tract nutrient digestibility coefficient sago meal $1 / 2 / 3 / 4 / 5=$ [(Nutrient digestibility coefficient ${ }_{\text {sagodiet }} \times$ Nutrient $\left._{\text {sagodiet }}\right)$ - Nutrient digestibility coefficient basaldiet $\times(0.75 \times$ Nutrient $\left.\left._{\text {basaldiet }}\right)\right]$ / $0.25 \times$ nutrient $_{\text {sago }}$

\section{Experiment II: Performance Trial}

Birds. A total of 200 one-day-old broiler chicks (unsexed, Cobb strain) obtained from a local commercial hatchery were randomly allocated into 20 pens (10 birds/pen).

Feed ingredients. Sago (Putak meal) and Probio FMplus were used in the second experiment. Probio FM ${ }^{\text {plus }}$ is a synbiotics product commercially produced by Kupang State Agriculture Polytechnic, Indonesia. The product contains a number of lactic acid bacteria (Lactobacillus brevis, Lactobacillus fermentum, Lactobacillus plantarum, and Pediacoccus pentosaceus) in an amount ranging from 36.1 $\times 10^{11}$ to $210 \times 10^{11} \mathrm{CFU} / \mathrm{mL}$, with the $\mathrm{pH}$ between 3.00 and 3.40. The dosage of Probio FM $M^{\text {plus }}$ used was $20 \mathrm{~mL} / \mathrm{L}$ drinking water.

Experimental design. A completely randomized design with a $2 \times 2$ factorial arrangement was implemented during the 28-day experiment (Gomez and Gomez, 1984). The first main factor was the basal diet (with and without sago) and the second main factor was synbiotics Probio $F M^{\text {plus }}$ (+ and -). A one-phase feeding program was employed in this study. The experimental diets (isonitrogenous and isoenergetic) (Table 2) were offered ad libitum in a crumble form to five replicate pens of broilers (10 birds/ pen) during the 28-day experiment. Synbiotics Probio $F M^{\text {plus }}$ was provided through drinking water $(20 \mathrm{~mL} / \mathrm{L})$ for 8 hours every day during the experimental period. After 8 hours, the birds were given drinking water without any feed additives.

Data collection. The initial body weight of birds was measured on day 0 . Body weight and feed intake data were recorded weekly; while, mortality data were recorded on a daily basis. Mortality data were used to correct the calculation of feed conversion ratio (FCR).

Statistical analysis. The chemical composition, antinutritional constituent, apparent metabolizable energy, and nutrient digestibility data obtained from this experiment were analyzed using the one-way analysis of variance (ANOVA); while the performance data were analyzed using two-way ANOVA according to the General Linear Model procedure of SAS (University Edition, SAS Institute). With regard to the apparent metabolizable energy, nutrient digestibility, and performance data, the cage was used as the experimental unit. Differences between treatments were calculated to be significant at $p<0.05$. Significant differences between the treatment means were further calculated using Fisher's Least Significant Difference Test (LSD).

\section{RESULTS}

\section{Chemical Composition of Sago from Different Locations in West Timor, Indonesia}

The proximate, calcium, phosphor, starch, and gross energy compositions of sago from different locations are summarized in Table 3. Significant differences $(p<0.05$ to 0.01$)$ were observed in these variables, except 
in crude lipid, ash, starch, and gross energy. The dry matter and crude fiber contents of Bipolo sago samples were lower $(\mathrm{p}<0.05)$ compared to sago samples from Naibonat $(1,2)$, Pariti, and Lili. However, the crude protein content of sago samples from Bipolo was sig-

Table 2. Composition ( $\mathrm{g} / 100 \mathrm{~g}$, as fed) of treatment diets (Experiment 2)

\begin{tabular}{lcc}
\hline Feed ingredients (\%) & Basal diet & Sago diet \\
\hline Maize & 48.50 & 40.00 \\
Sago (Putak meal) & - & 8.50 \\
Rice bran & 5.00 & 5.00 \\
Soybean meal 44.0\% CP & 32.48 & 32.48 \\
Fish meal & 5.00 & 5.00 \\
Meat and bone meal & 5.00 & 5.00 \\
Vegetable oil & 2.00 & 2.00 \\
L-Lysine HCl & 0.25 & 0.25 \\
DL-Methionine & 0.05 & 0.05 \\
Limestone feed grade & 0.50 & 0.50 \\
Dicalcium phosphate Ca22/P18 & 0.60 & 0.60 \\
Salt & 0.25 & 0.25 \\
Sodium bicarbonate & 0.07 & 0.07 \\
Vitamin dan mineral premix ${ }^{1}$ & 0.30 & 0.30 \\
Total & 100 & 100 \\
Calculated nutrient composition & & \\
(g/kg as fed) & & \\
$\quad$ Apparent metabolizable & 2,830 & 2,830 \\
$\quad$ energy (kcal/kg) & & \\
Crude protein & 226 & 226 \\
Crude fiber & 33.9 & 33.9 \\
Lysine & 14.8 & 14.8 \\
Met+Cys & 10.1 & 10.1 \\
Calcium & 13.6 & 13.5 \\
$\quad$ Av Phosphorus & 5.3 & 5.3 \\
\hline
\end{tabular}

Note: ${ }^{1}=$ Sanmix (PT Sanbe Farma), per kg provided: Vit A (1250000 IU), Vit D3 (250000 IU), Vit E (750 IU), Vit K (200 mg), Vit B1 (150 mg) Vit B2 (500 mg), Vit B6 (500 mg), Vit B12 (1012 mcg), Vit C (3000 $\mathrm{mg})$, Ca-d-pantothenate $(500 \mathrm{mg})$, niacin $(3500 \mathrm{mg})$, methionine (3500 mg), lysine (3500 mg), manganese (10000 mg), iron (2500 $\mathrm{mg})$; iodine $(20 \mathrm{mg})$, zinc $(10000 \mathrm{mg})$, cobalt $(20 \mathrm{mg})$, copper (300 $\mathrm{mg})$, and antioxidant (1000 mg). nificantly $(p<0.05)$ higher than those from Naibonat $(1$, $2)$, Pariti, and Lili. Although there was no significant difference $(p>0.05)$ in gross energy among all sago samples, the Pariti sago had higher gross energy content compared to sago samples from other locations.

The dry matter contents of sago samples varied within the restricted range, from 88.18 to $89.94 \mathrm{~g} / 100$ $\mathrm{g}$ as fed (Table 3$)$. The crude fat and crude protein contents of sago were low, with an average value of $0.501 \mathrm{~g} / 100 \mathrm{~g}$ DM and $2.41 \mathrm{~g} / 100 \mathrm{~g}$ DM, respectively. Sago had a crude fiber content ranging from 3.355 to 6.565 $\mathrm{g} / 100 \mathrm{~g}$ DM, while the ash content of sago ranged from 2.470 to $5.230 \mathrm{~g} / 100 \mathrm{~g}$ DM. The mineral data showed that the calcium $(\mathrm{Ca})$ and phosphorus $(\mathrm{P})$ contents of sago were low, with values ranging between 0.130 and 0.380 $\mathrm{g} / 100 \mathrm{~g}$ DM and between 0.04 and $0.08 \mathrm{~g} / 100 \mathrm{~g}$ DM, respectively. Sago contained high concentration of starch which ranged from 59.12 to $69.32 \mathrm{~g} / 100 \mathrm{~g}$ DM. The gross energy content of sago ranged from 4248.45 to 4391.65 $\mathrm{kcal} / \mathrm{kg}$ DM.

Table 4 presents the amino acid contents of sago from different locations in West Timor, Indonesia. The highest lysine content was observed in the Naibonat sago, whilst the lowest lysine content was found in Bipolo and Lili sago. The lysine content of sago ranged from 0.102 to $0.174 \mathrm{~g} / 100 \mathrm{~g} \mathrm{DM}$, with an average of 0.124 $\mathrm{g} / 100 \mathrm{~g}$ DM. The content of methionine in sago ranged from 0.022 to $0.034 \mathrm{~g} / 100 \mathrm{~g} \mathrm{DM}$, while cysteine ranged from 0.011 to $0.017 \mathrm{~g} / 100 \mathrm{~g}$ DM.

Table 5 presents the anti-nutrient content of sago from different locations in West Timor, Indonesia. Tannin, phytic acid, NDF, ADF, total phenol, and flavonoids are anti-nutrients found in sago. Except for total phenol and phytic acid, statistical analysis showed that location significantly affected $(p<0.05-0.01)$ tannin, NDF, $\mathrm{ADF}$, and flavonoid contents of sago.

Sago samples from Naibonat 1 and Naibonat 2 had similar $(\mathrm{p}>0.05)$ tannin contents with sago samples from Lili, but they were higher $(p<0.05)$ than those from Pariti and Bipolo. The tannin content of sago was low, with values ranging from 0.011 to $0.180 \mathrm{~g} / 100 \mathrm{~g}$ DM.

The phytic acid contents of sago from all locations ranged from 1.187 to $1.142 \mathrm{~g} / 100 \mathrm{~g} \mathrm{DM}$, while the phenol

Table 3. Nutrient composition of sago (putak) obtained from different locations in West Timor, Indonesia

\begin{tabular}{|c|c|c|c|c|c|c|c|c|c|}
\hline \multirow[b]{2}{*}{$\begin{array}{c}\text { Sago sample } \\
\text { locations }\end{array}$} & \multicolumn{9}{|c|}{ Nutrient composition } \\
\hline & $\begin{array}{l}\text { Dry matter } \\
(\mathrm{g} / 100 \mathrm{~g})\end{array}$ & $\begin{array}{c}\text { Crude pro- } \\
\text { tein }(\mathrm{g} / 100 \mathrm{~g} \\
\mathrm{DM})\end{array}$ & $\begin{array}{l}\text { Crude lipid } \\
\text { (g/100g DM) }\end{array}$ & $\begin{array}{l}\text { Crude fiber } \\
\text { (g/100g DM) }\end{array}$ & $\begin{array}{c}\text { Ash } \\
\text { (g/100g } \\
\text { DM) }\end{array}$ & $\begin{array}{l}\text { Starch } \\
(\mathrm{g} / 100 \mathrm{~g} \\
\text { DM) }\end{array}$ & $\begin{array}{c}\mathrm{Ca} \\
(\mathrm{g} / 100 \mathrm{~g} \\
\mathrm{DM})\end{array}$ & $\begin{array}{c}\mathrm{P}(\mathrm{g} / 100 \mathrm{~g} \\
\mathrm{DM})\end{array}$ & $\begin{array}{l}\text { GE (MJ/ } \\
\text { kgDM) }\end{array}$ \\
\hline Naibonat 1 & $88.88^{a}$ & $2.26^{\mathrm{b}}$ & 0.290 & $6.37^{a}$ & 2.47 & 61.08 & 0.24 & 0.04 & 18.10 \\
\hline Naibonat 2 & $89.96^{\mathrm{a}}$ & $2.25^{\mathrm{b}}$ & 0.687 & 3.48 & 4.31 & 67.94 & 0.27 & 0.08 & 17.84 \\
\hline Pariti & $88.91^{\mathrm{a}}$ & $2.23^{b}$ & 0.335 & $6.56^{\mathrm{a}}$ & 3.00 & 63.93 & 0.23 & 0.06 & 18.38 \\
\hline Bipolo & $88.18^{b}$ & $3.17^{\mathrm{a}}$ & 0.535 & $3.35^{\mathrm{b}}$ & 4.90 & 69.32 & 0.13 & 0.08 & 17.78 \\
\hline Lili & $89.44^{a}$ & $2.01^{\mathrm{b}}$ & 0.660 & $6.23^{\mathrm{a}}$ & 5.23 & 59.20 & 0.38 & 0.08 & 17.92 \\
\hline Average & 88.86 & 2.41 & 0.501 & 5.20 & 3.98 & 64.28 & 0.25 & 0.07 & 0.036 \\
\hline SEM & 0.520 & 0.434 & 0.208 & 0.08 & 0.737 & 0.156 & 0.08 & 0.02 & 71.09 \\
\hline $\operatorname{Pr}>F$ & * & * & NS & $* *$ & NS & NS & * & * & NS \\
\hline
\end{tabular}

Note: Means in the same column with different superscripts differ significantly $(\mathrm{p}<0.05){ }^{*}=$ Differ significantly $(\mathrm{p}<0.05) ;{ }^{* *}=\mathrm{Highly}$ significant $(\mathrm{p}<0.01)$; $\mathrm{NS}=$ Not significant; GE $=$ Gross energy. Each value is the average of 2 replicates. 
Table 4. Amino acid (g/100 g DM) contents of sago (putak) obtained from different locations in West Timor, Indonesia

\begin{tabular}{|c|c|c|c|c|c|c|c|c|}
\hline \multirow{2}{*}{ Amino acids } & \multicolumn{5}{|c|}{ Sago sample location } & \multirow{2}{*}{ Ave } & \multirow{2}{*}{ SEM } & \multirow{2}{*}{$\operatorname{Pr}>\mathrm{F}$} \\
\hline & Naibonat 1 & Naibonat 2 & Pariti & Bipolo & Lili & & & \\
\hline \multicolumn{9}{|l|}{ Essential } \\
\hline Arginine & 0.051 & 0.034 & 0.028 & 0.034 & 0.028 & 0.035 & 0.002 & NS \\
\hline Histidine & 0.023 & 0.017 & 0.017 & 0.017 & 0.011 & 0.017 & 0.001 & NS \\
\hline Isoleucine & 0.051 & 0.045 & 0.045 & 0.034 & 0.034 & 0.042 & 0.002 & NS \\
\hline Lysine & 0.174 & 0.123 & 0.118 & 0.102 & 0.101 & 0.124 & 0.007 & NS \\
\hline Methionine & 0.028 & 0.022 & 0.034 & 0.023 & 0.028 & 0.027 & 0.001 & NS \\
\hline Phenylalanine & 0.051 & 0.034 & 0.039 & 0.028 & 0.028 & 0.036 & 0.002 & NS \\
\hline Threonine & 0.090 & 0.080 & 0.080 & 0.090 & 0.100 & 0.088 & 0.002 & NS \\
\hline Valine & 0.023 & 0.017 & 0.028 & 0.011 & 0.067 & 0.029 & 0.005 & NS \\
\hline \multicolumn{9}{|l|}{ Nonessential } \\
\hline Alanine & 0.120 & 0.120 & 0.140 & 0.150 & 0.120 & 0.130 & 0.003 & NS \\
\hline Aspartic acid & 0.170 & 0.160 & 0.190 & 0.200 & 0.180 & 0.180 & 0.004 & NS \\
\hline Cystine & 0.017 & 0.017 & 0.017 & 0.011 & 0.011 & 0.015 & 0.001 & NS \\
\hline Glycine & 0.135 & 0.123 & 0.135 & 0.272 & 0.123 & 0.158 & 0.014 & NS \\
\hline Glutamic acid & 0.305 & 0.280 & 0.290 & 0.360 & 0.280 & 0.303 & 0.007 & NS \\
\hline Proline & 0.068 & 0.067 & 0.062 & 0.068 & 0.061 & 0.065 & 0.001 & NS \\
\hline Serine & 0.090 & 0.080 & 0.100 & 0.110 & 0.110 & 0.098 & 0.003 & NS \\
\hline Tyrosine & 0.039 & 0.034 & 0.051 & 0.034 & 0.028 & 0.037 & 0.002 & NS \\
\hline
\end{tabular}

Note: NS = Not significant. Each value is the average of 2 replicates.

Table 5. Anti-nutrient composition of sago (putak) obtained from different locations in West Timor, Indonesia

\begin{tabular}{lcccccc}
\hline $\begin{array}{c}\text { Sago sample } \\
\text { locations }\end{array}$ & $\begin{array}{c}\text { Tannin } \\
(\mathrm{g} / 100 \mathrm{~g} \text { DM })\end{array}$ & $\begin{array}{c}\text { Phytic acid } \\
(\mathrm{g} / 100 \mathrm{~g} \text { DM })\end{array}$ & $\begin{array}{c}\text { NDF } \\
(\mathrm{g} / 100 \mathrm{~g} \mathrm{DM})\end{array}$ & $\begin{array}{c}\text { ADF } \\
(\mathrm{g} / 100 \mathrm{~g} \mathrm{DM})\end{array}$ & $\begin{array}{c}\text { Total phenol } \\
(\mathrm{g} / 100 \mathrm{~g} \text { DM })\end{array}$ & $\begin{array}{c}\text { Flavonoids } \\
(\mathrm{mg} / \mathrm{kg} \mathrm{DM})\end{array}$ \\
\hline Naibonat 1 & $0.180^{\mathrm{a}}$ & 1.252 & $23.67^{\mathrm{a}}$ & $10.43^{\mathrm{a}}$ & 0.371 & $356^{\mathrm{c}}$ \\
Naibonat 2 & $0.152^{\mathrm{a}}$ & 1.266 & $14.92^{\mathrm{a}}$ & $7.03^{\mathrm{b}}$ & 0.354 & $2630^{\mathrm{a}}$ \\
Pariti & $0.011^{\mathrm{b}}$ & 1.412 & $24.80^{\mathrm{a}}$ & $10.93^{\mathrm{a}}$ & 0.146 & $2716^{\mathrm{a}}$ \\
Bipolo & $0.056^{\mathrm{b}}$ & 1.232 & 16.08 & $5.81^{\mathrm{b}}$ & 0.191 & $1270^{\mathrm{b}}$ \\
Lili & $0.146^{\mathrm{a}}$ & 1.187 & $23.72^{\mathrm{a}}$ & $9.85^{\mathrm{a}}$ & 0.343 & $2866^{\mathrm{a}}$ \\
Average & 0.109 & 1.270 & 20.64 & 8.81 & 0.281 & 1968 \\
SEM & 0.02 & 0.02 & 1.06 & 0.51 & 0.02 & $* 2.83$ \\
Pr > F & $* *$ & NS & $* *$ & $*$ & $*$ & $*$ \\
\hline
\end{tabular}

Note: Means in the same column with different superscripts differ significantly $(\mathrm{p}<0.05) .{ }^{*}=$ Differ significantly $(\mathrm{p}<0.05) ;{ }^{* *}=$ Highly significant $(\mathrm{p}<0.01)$; $\mathrm{NS}=$ Not significant; NDF= Neutral Detergent Fiber; ADF $=$ Acid Detergent Fiber. Each value is the average of 2 replicates

content varied from 0.146 to $0.371 \mathrm{~g} / 100 \mathrm{~g}$ DM. In addition to starch, sago carbohydrates were also characterized by a high concentration of NDF (Table 3 and 5). The NDF and ADF contents of sago from Naibonat 1 , Pariti, and Lili were similar $(p>0.05)$. No significant differences in ADF and NDF contents were found between sago samples from Naibonat 2 and Bipolo. The ADF and NDF content of sago samples from Naibonat 2 and Bipolo were significantly lower $(p<0.05)$ than those from Naibonat 1, Pariti, and Lili. The flavonoid content of sago from Naibonat 1 was the lowest $(p<0.05)$ compared with sago samples from other locations. On average, the NDF and ADF contents of sago were $20.64 \mathrm{~g} / 100 \mathrm{~g}$ DM and $8.81 \mathrm{~g} / 100 \mathrm{~g} \mathrm{DM}$, respectively (Table 5). There were no significant differences in flavonoid contents observed between sago samples in Naibonat 2, Pariti, and Lili. The average flavonoid content of all sago samples was $1968 \mathrm{~g} / 100 \mathrm{~g}$ DM.

\section{The Apparent Metabolizable Energy Values and Starch Digestibility Coefficients of Sago from Different Locations in West Timor, Indonesia}

Table 6 presents the apparent metabolizable energy values and total tract starch digestibility coefficients of sago from different locations in West Timor, Indonesia. Significant differences $(p<0.05)$ were observed in the apparent metabolizable energy values (AME/n) of sago from different locations.

The apparent metabolizable energy (AME) and nitrogen-corrected apparent metabolizable energy (AMEn) values of sago from Pariti were significantly lower $(p<0.05)$ than the AME and AMEn values of sago from Naibonat $(1,2)$, Bipolo, and Lili. The AME and AMEn values of sago ranged from 8.25 to $11.98 \mathrm{MJ} / \mathrm{kg}$ DM and 7.87 to 11.39 MJ.kg DM, respectively. The average AME and AMEn values of sago were 10.75 and 10.47 $\mathrm{MJ} / \mathrm{kg} \mathrm{DM}$, respectively. 
The correlation coefficient $(r)$ between AMEn values and the starch digestibility coefficients of sago are described in Figure 2. The correlation coefficient (r) between AMEn values and the starch digestibility coefficient of sago was $0.749\left(\mathrm{r}^{2}=0.561\right)$. This computed $r$ value $(r=0.749)$ was less than the tabular $r$ value at the $5 \%$ level $(r=0.878)$, indicating that the simple linear correlation coefficient was not significant. Therefore, the AMEn values and starch digestibility coefficient of sago were not linearly associated with one another.

The starch digestibility coefficients of sago from different locations in West Timor, Indonesia varied significantly $(\mathrm{p}<0.05)$. As presented in Table 6, the digestibility coefficients of sago starch were found to be similar among all treatments. The digestibility coefficients of starch ranged between 0.537 in sago from Pariti and 0.702 in sago from Naibonat 1, with an average of 0.637 .

Statistical analysis showed that there was a positive correlation $(r=0.673)$ between the AMEn values and NDF contents of sago (Figure 3). The correlation coefficient (r) between AMEn values and the starch digest-

Table 6. Apparent metabolizable energy values (AME), nitrogen-correction apparent metabolizable energy values (AMEn), and total tract starch digestibility coefficient of sago (putak) from different locations in West Timor, Indonesia

\begin{tabular}{lccc}
\hline $\begin{array}{c}\text { Sago sample } \\
\text { locations }\end{array}$ & $\begin{array}{c}\text { AME } \\
(\mathrm{MJ} / \mathrm{kg} \mathrm{DM})\end{array}$ & $\begin{array}{c}\text { AMEn } \\
(\mathrm{MJ} / \mathrm{kg} \mathrm{DM})\end{array}$ & $\begin{array}{c}\text { Starch } \\
\text { digestibility } \\
\text { coefficient }\end{array}$ \\
\hline Naibonat 1 & $11.14^{\mathrm{a}}$ & $11.10^{\mathrm{a}}$ & 0.702 \\
Naibonat 2 & $11.98^{\mathrm{a}}$ & $11.39^{\mathrm{a}}$ & 0.621 \\
Pariti & $8.25^{\mathrm{b}}$ & $7.87^{\mathrm{b}}$ & 0.537 \\
Bipolo & $11.39^{\mathrm{a}}$ & $11.17^{\mathrm{a}}$ & 0.696 \\
Lili & $10.99^{\mathrm{a}}$ & $10.83^{\mathrm{a}}$ & 0.628 \\
Average & 10.75 & 10.47 & 0.637 \\
SEM & 0.827 & 0.737 & 0.072 \\
Pr $>$ F & $* *$ & $* *$ & NS \\
\hline
\end{tabular}

Note: a,bMeans in the same column with different superscripts differ significantly $(\mathrm{p}<0.05) .{ }^{* *}=$ Highly significant $(\mathrm{p}<0.01)$; NS= Not significant. Each value is the average of 4 replicates ( 5 birds/cage).

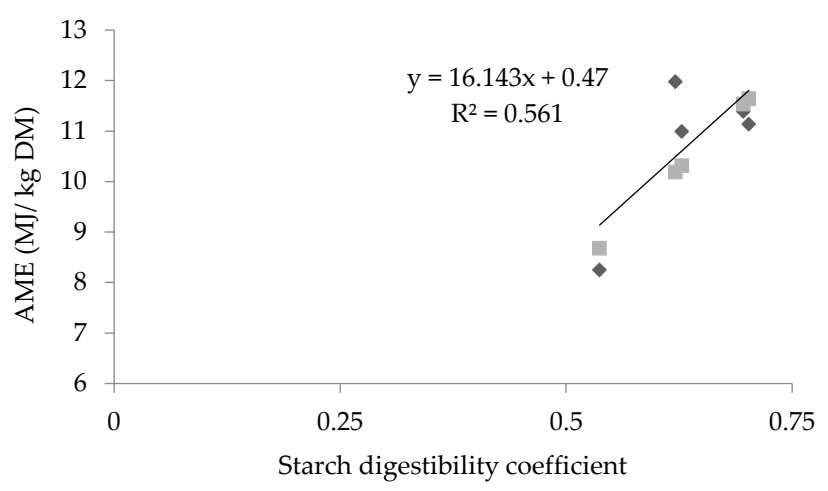

Figure 2. The correlation between the apparent metabolizable energy (AME) values and starch digestibility coefficients of sago (putak). = AMEn (MJ/kg DM); $=$ Predicted AMEn (MJ/kg DM); — = Linear (AMEn (MJ/ $\mathrm{kg}$ DM)). ibility coefficients of sago was $0.673\left(\mathrm{r}^{2}=0.453\right)$. The calculated $r$ value $(r=0.673)$ was lower than the tabular $r$ value at the $5 \%$ level $(\mathrm{df}=3 ; \mathrm{r}=0.878)$, meaning that the calculated $\mathrm{r}$ of 0.673 was confirmed to be nonsignificant at $5 \%$ level. This insignificancy proved that the AME values were not correlated to the NDF content of sago.

\section{The Amino Acid Digestibility Coefficients of Diets Containing Sago from Different Locations in West Timor, Indonesia}

As shown in Table 7, with the exception of arginine, histidine, and leucine, the amino acid digestibility coefficients of diets containing sago (putak) from different locations were not different. In general, the amino acid digestibility coefficients of diets containing putak from Naibonat 2 were higher than the amino acid digestibility coefficient of diets containing putak from other locations. The digestibility coefficient of arginine of birds fed on diets containing sago from Naibonat 2 was significantly higher $(p<0.01)$ than those given diets containing sago from Naibonat 1, Bipolo, and Lili; however, it was similar to a group of birds fed diets containing sago from Pariti location.

The digestibility coefficients of lysine in the diets containing $250 \mathrm{~g} / \mathrm{kg}$ of sago from all locations ranged from 0.480 to 0.698 ; while the digestibility coefficients of methionine ranged from 0.393 to 0.551 .

\section{The Performance of Birds Fed Different Basal Diets Added with Synbiotics}

The effects of feeding different basal diets added with synbiotics Probio FM ${ }^{\text {plus }}$ through drinking water on the performance of broilers are summarized in Table 8 . There was no interaction between basal diets, and synbiotics supplementation $(p>0.05)$ was found for all performance traits. The body weight gain (BWG), feed intake (FI), feed efficiency, mortality rate, and carcass percentage of birds fed on sago basal diets were significantly higher $(\mathrm{p}<0.05$ to 0.001$)$ than those of maize-soybean meal basal diets. The BWG, FI, and feed conversion ratio (FCR) of birds fed sago basal diets were 779 g/bird, 1176

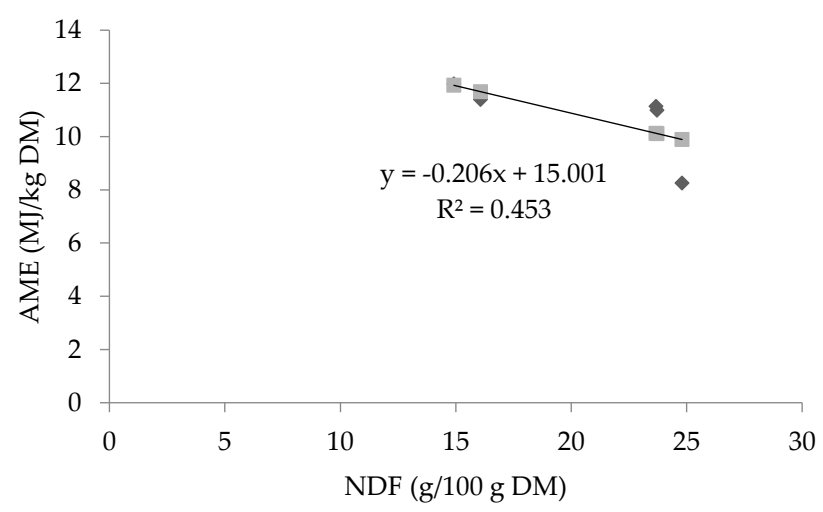

Figure 3. The correlation between the apparent metabolizable energy (AME) and the nutrien digisetible fiber (NDF) content of sago (putak). = AMEn (MJ/kg DM); = Predicted AMEn (MJ/kg DM); — = Linear (AMEn (MJ/ $\operatorname{kg} \mathrm{DM})$ ) 
$\mathrm{g} / \mathrm{bird}$, and $2.15 \mathrm{~g} / \mathrm{g}$, respectively. In contrast, averages BWG, FI, and FCR of birds receiving maize-soybean meal basal diets were only $420 \mathrm{~g} / \mathrm{bird}, 1692 \mathrm{~g} / \mathrm{bird}$, and $2.72 \mathrm{~g} / \mathrm{g}$, respectively. The carcass recovery in the group of birds fed sago basal diets was higher $(60.9 \%)$ than that in birds fed maize-SBM basal diets.

Except for body weight gain, the addition of synbiotics Probio FM ${ }^{\text {plus }}$ had no significant effects $(\mathrm{p}>0.05)$ on feed intake, feed efficiency, mortality rate, and carcass percentage of growing broilers. The BWG of birds fed diets added with synbiotics Probio FMplus through drinking water was lower (589 g/bird) than those in the control group (610 g/bird).

\section{DISCUSSION}

In general, sago (putak) obtained from the pith of the gebang tree (Corypha utan Lamk), has the potential to be used as an energy source in poultry diets based on the chemical composition results. Sago (putak) contains

Table 7. Total tract amino acid digestibility coefficients of birds fed diets containing $250 \mathrm{~g} / \mathrm{kg}$ sago (putak meal) obtained from different locations in West Timor, Indonesia

\begin{tabular}{|c|c|c|c|c|c|c|c|}
\hline \multirow{2}{*}{ Amino acids } & \multicolumn{5}{|c|}{ Sago sample locations } & \multirow{2}{*}{ SEM } & \multirow{2}{*}{$\operatorname{Pr}>F$} \\
\hline & Naibonat 1 & Naibonat 2 & Pariti & Bipolo & Lili & & \\
\hline \multicolumn{8}{|l|}{ Essential } \\
\hline Arginine & $0.726^{\mathrm{bc}}$ & $0.922^{\mathrm{a}}$ & $0.825^{\mathrm{ab}}$ & $0.649^{\mathrm{cd}}$ & $0.548^{\mathrm{d}}$ & 0.0042 & 0.0001 \\
\hline Histidine & $0.652^{c}$ & $0.870^{\mathrm{a}}$ & $0.787^{b}$ & $0.788^{b}$ & $0.662^{c}$ & 0.0258 & $<0.0001$ \\
\hline Isoleucine & 0.556 & 0.718 & 0.618 & 0.592 & 0.583 & 0.0466 & 0.1817 \\
\hline Leucine & $0.657^{\mathrm{ab}}$ & $0.772^{\mathrm{a}}$ & $0.547^{b}$ & $0.613^{b}$ & $0.653^{\mathrm{ab}}$ & 0.0439 & 0.0311 \\
\hline Lysine & 0.656 & 0.698 & 0.494 & 0.682 & 0.633 & 0.0480 & 0.0587 \\
\hline Methionine & 0.500 & 0.551 & 0.393 & 0.518 & 0.391 & 0.0376 & 0.0260 \\
\hline Threonine & 0.638 & 0.758 & 0.732 & 0.589 & 0.698 & 0.0294 & 0.2051 \\
\hline Valine & 0.487 & 0.706 & 0.608 & 0.521 & 0.470 & 0.0516 & 0.2275 \\
\hline \multicolumn{8}{|l|}{ Nonessential } \\
\hline Alanine & 0.310 & 0.691 & 0.145 & 0.323 & 0.330 & 0.0740 & 0.2224 \\
\hline Aspartic acid & 0.444 & 0.627 & 0.502 & 0.383 & 0.534 & 0.0553 & 0.0572 \\
\hline Cystine & 0.411 & 0.535 & 0.393 & 0.518 & 0.391 & 0.0542 & 0.0531 \\
\hline Glutamic acid & 0.712 & 0.721 & 0.648 & 0.613 & 0.652 & 0.0714 & 0.7959 \\
\hline Tyrosine & 0.745 & 0.781 & 0.650 & 0.644 & 0.739 & 0.0385 & 0.2429 \\
\hline
\end{tabular}

Note: Means in the same column with different superscripts differ significantly ( $\mathrm{p}<0.05)$. Each value is the average of 4 replicates $(5$ birds/replicate).

Table 8. Performance of growing broilers fed different basal diets containing Symbiotic Probio FMplus ${ }^{1}$ (28 days post hatch, Experiment 2)

\begin{tabular}{|c|c|c|c|c|c|c|}
\hline \multirow[b]{2}{*}{ Basal diets } & \multirow[b]{2}{*}{$\begin{array}{c}\text { Synbiotics } \\
\text { Probio FMplus }\end{array}$} & \multicolumn{5}{|c|}{ Variables } \\
\hline & & $\begin{array}{l}\text { BWG } \\
\text { (g/bird) }\end{array}$ & $\begin{array}{c}\text { FI } \\
\text { (g/bird) }\end{array}$ & $\begin{array}{l}\text { FCR } \\
(\mathrm{g} / \mathrm{g})\end{array}$ & $\begin{array}{c}\text { Mortality } \\
(\%)\end{array}$ & $\begin{array}{c}\text { Carcass } \\
\text { percentage }(\%)\end{array}$ \\
\hline Maize-SBM & - & 416 & 1172 & 2.85 & 10.0 & 56.1 \\
\hline Maize-SBM & + & 440 & 1180 & 2.75 & 5.0 & 57.4 \\
\hline Maize-sago-SBM & - & 822 & 1766 & 2.15 & 0.0 & 60.4 \\
\hline Maize-sago-SBM & + & 759 & 1619 & 2.15 & 3.3 & 61.4 \\
\hline SEM & & 30.29 & 56.49 & 0.120 & 2.0 & 0.94 \\
\hline \multicolumn{7}{|l|}{ Main factor I, Basal Diets } \\
\hline Maize-SBM & & $420^{b}$ & $1176^{\mathrm{b}}$ & $2.72^{\mathrm{a}}$ & $7.5^{\mathrm{a}}$ & $56.8^{\mathrm{b}}$ \\
\hline Maize-sago-SBM & & $779 a$ & $1692^{a}$ & $2.15^{\mathrm{b}}$ & $1.7^{\mathrm{b}}$ & $60.9^{a}$ \\
\hline SEM & & 21.41 & 39.95 & 0.08 & 1.42 & 0.66 \\
\hline \multicolumn{7}{|l|}{ Main factor II, Symbiotic Probio FMplus } \\
\hline- & & $610^{\mathrm{a}}$ & $1470^{\mathrm{a}}$ & $2.45^{\mathrm{a}}$ & $5.0^{\mathrm{a}}$ & $58.3^{\mathrm{a}}$ \\
\hline+ & & $589^{b}$ & $1400^{\mathrm{a}}$ & $2.42^{\mathrm{a}}$ & $4.2^{\mathrm{a}}$ & $59.4^{\mathrm{a}}$ \\
\hline SEM & & 21.41 & 39.95 & 0.08 & 1.42 & 0.66 \\
\hline \multicolumn{7}{|l|}{ Probability } \\
\hline Basal Diets & & * & * & * & * & $* * *$ \\
\hline Symbiotic Probio FM $M^{\text {plus }}$ & & * & NS & NS & NS & NS \\
\hline Basal Diets $x$ Symbiotic Probio FMplus & & NS & NS & NS & NS & NS \\
\hline
\end{tabular}

Note: Means in the same column with different superscripts differ significantly $(p<0.05)$. NS= Not Significant; ${ }^{*}=$ Significant $(p<0.05) ;{ }^{* * *}=$ Highly Significant $(\mathrm{p}<0.001)$. Each value is the average of 5 replicates $(10$ birds/cage). 
all the essential nutrients needed by poultry, with starch being the major nutrient in sago (Table 3). However, sago also contains several anti-nutrients such as tannin, phytic acid, neutral detergent fiber (NDF), phenol, and flavonoids (Table 5) which could affect the nutrient digestibility and performance of broiler chickens (Cho et al., 2019; Tomaszewska et al., 2018; Ouyang et al., 2016; Truong et al., 2015; Rohollah et al., 2015; Woyengo \& Nyachotti, 2013).

The results of the present study indicate that the nutrient composition of sago varies according to the location (Table 3 and Table 5). The differences in nutrient composition of sago from the different locations are probably due to the differences in soil fertility, the age of harvesting, and the presence of toxin. Nalle et al. (2019a) found ochratoxin $\mathrm{A}$ in a few sago samples. The results of this study are in accordance with Lee et al. (2016) reporting that location has a significant effect on the nutritional content of cereal grains namely maize, wheat, and barley. These authors evaluated the nutritional composition of 432 samples of maize and wheat from five different countries and 60 barley samples from three different countries. According to the authors (Lee et al., 2016), variation in the nutrient contents of maize, wheat, and barley might be owing to the differences in soil fertility, cultivar, and the presence of toxin. A study by Bulyaba et al. (2020) found that location only affected the yield and seed weight, but it did not affect the elemental composition of common bean seed.

Sago (putak) is rich in starch content (59.12 to 69.32 $\mathrm{g} / 100 \mathrm{DM})$, but poor in lipid (0.290 to $0.687 \mathrm{~g} / 100 \mathrm{~g} \mathrm{DM})$ and protein content (2.01 to $3.17 \mathrm{~g} / 100 \mathrm{~g} \mathrm{DM}$ ) (Table 1). It is also indicated from the present study that starch is the major carbohydrate component in sago (putak); thus, sago is an important source of energy for animals. The starch content of sago was nearly as much as the starch content of maize, which ranged from 61 to $78 \mathrm{~g} / 100 \mathrm{~g}$ (Ai \& Jane, 2016). However, the crude protein content of sago was lower than the crude protein content of maize. Ai \& Jane (2016) reported that the crude protein content of maize was 6 to $12 \mathrm{~g} / 100 \mathrm{~g}$, with the majority of protein located in the endosperm and germ. The crude protein of sago (putak) obtained in the present study was slightly lower than the crude protein content of sago (putak) reported by Nalle et al. (2017, 2019a), with the values ranging from 2.39 to $3.66 \mathrm{~g} / 100 \mathrm{~g}$ DM. The differences may be owing to the differences in sampling locations, time of harvesting, and the stem position of the gebang tree (bottom, middle, or top of the tree). Due to the low crude protein content of sago (compared to maize), when this feed ingredient is used to replace maize in the high amount in the diet, the crude protein content of the diet will decrease. Thus the diet formulator should increase the inclusion level of protein sources such as soybean meal or meat and bone meal. However, since the price of sago is cheaper than the price of maize, as a result the price per $\mathrm{kg}$ of sago diet is much lower than the price per $\mathrm{kg}$ of maize diet. The average of crude fiber content of sago (5.20 g/100 g DM) obtained in the present study was lower than the crude fiber content of sago published by Nalle et al. (2017) which was 9.95 g/100 g DM, but it was higher than that of Nalle et al. (2019a) which was $4.97 \mathrm{~g} / 100 \mathrm{~g}$ DM. The differences were likely because of a number of factors such as the different processing methods applied to produce sago (putak), location, and harvesting time. In this study, sago (putak) was obtained through grinding the pith (chopped) using a roller mill, whereas Nalle et al. (2017) used a machine specifically designed for pith (whole) grinding, resembling a coconut grinding machine. A roller mill is only designed for grinding a small size of material (i.e., chopped pith of the gebang tree). Thus there will be many fiber components removed during the grinding process. In contrast, the grinder used by Nalle et al. (2017) was designed for grinding the pith of gebang stem without being chopped.

The average ash content of sago samples in the present study was slightly lower (4.02 g/100 g DM) than the ash content reported by Nalle et al. (2017) which was $5.04 \mathrm{~g} / 100 \mathrm{~g}$ DM. This difference is likely due to the difference in location (i.e. soil type and mineral availability) and harvesting time. The mineral composition of sago indicated that this feed ingredient contained negligible levels of calcium and phosphor, with average values of 0.25 and $0.07 \mathrm{~g} / 100 \mathrm{~g} \mathrm{DM}$, respectively.

The results of the present study show that sago contains several anti-nutrients namely fiber (Neutral Detergent Fiber, NDF), phytic acid, tannin, phenol, and flavonoids which become other limiting factors in poultry diet formulation. Fiber (NDF or non-starch polysaccharides, NSP) is categorized as an anti-nutritional factor for birds because it contains undigested components including cellulose, hemicellulose, pectin, and lignin which cannot be digested in the small intestine of birds (Mtei et al., 2019; Yacout, 2016; Slominsky, 2011). The physicochemical properties of fiber are responsible for their antinutritive activities in the broilers (Raza et al., 2019; Mateos et al., 2012). NDF is the major anti-nutritional factor in sago (20.64 g/100 g DM). The NDF level of sago in the present study is slightly lower than the value $(21.46 \mathrm{~g} / 100 \mathrm{DM})$ reported by Nalle et al. (2019a). The phytic acid content of sago (1.232 to 1.412 $\mathrm{g} / 100 \mathrm{~g} \mathrm{DM}$ ) was lower than the values (2.86 to 3.37 $\mathrm{g} / 100 \mathrm{~g}$ DM) reported by Nalle et al. (2019a). The tannin content of sago evaluated was lower than that of Nalle et al. (2019a). The differences in anti-nutrient contents were probably due to environmental factors such as location (soil fertility rate), year of harvest, and processing method (Choct et al., 1999; Nalle et al., 2017).

Based on the results of the amino acid content, it appears that sago contains a very low amount of amino acids. Therefore, if sago is used in the ration, it is necessary to supplement it with synthetic amino acids. The averages of apparent metabolizable energy (AME) and nitrogen-corrected AME of sago (putak) were 10.75 and $10.47 \mathrm{MJ} / \mathrm{kg} \mathrm{DM}$, respectively. The lowest AME and AMEn values were observed in sago obtained from Pariti area; while the highest AME and AMEn were found in sago from Naibonat 2 area.

The apparent metabolizable energy (AME) values of sago (putak) were found to be not affected by NDF concentration and starch digestibility coefficient (Figures 2 and 3). The result in the present study was in agreement with Smeets et al. (2018), who found that 
there was no relationship between the AME values and fiber concentration (Smeets et al., 2018). Azhar et al. (2019) proved that the AME and N-corrected AME of 17 wheat samples used in the UK poultry feed industry, with the total NSP content ranged from 80.1 to 98.2), were comparable. However, some researchers (Sharif et al., 2012; Ball et al., 2013; Smeets et al., 2015; Truong et al., 2015) claimed that fiber (non-starch polysaccharides, NSP) concentration negatively affected the AME values. Karunaratne et al. (2018) reported that there was no correlation between the Canadian wheat AME values and starch digestibility (in vitro or in vivo).

Regarding the starch digestibility, the present study showed that location did not affect the digestibility coefficient of starch. This condition was possibly due to the starch contents of all sago samples from different locations were similar (Table 3). Other possibilities are probably because of the starch structure, the granule size of starch, the ratio and interaction between amylose and amylopectin are almost the same among all sago samples from different locations (Amerah, 2015; Svihus, 2014).

The digestibility coefficients of lysine and methionine of diets containing sago (putak) obtained from all locations were too low (Table 6). Therefore, when a basal diet is formulated to contain $250 \mathrm{~g} / \mathrm{kg}$ of sago for growing broilers, it needs to be supplemented with L-lysine $\mathrm{HCl}$ for about 0.3 to $0.5 \%$ of the diet and DL-methionine for about 0.2 to $0.3 \%$ of the diet. The amino acid digestibility coefficient of diets containing $250 \mathrm{~g} / \mathrm{kg}$ of sago was too low, so it is suggested that the inclusion level of sago in the diets for starting broilers should not be 250 $\mathrm{g} / \mathrm{kg}$. Nalle et al. (2017) reported that the inclusion level of sago for $200 \mathrm{~g} / \mathrm{kg}$ in starting broiler diets did not have a detrimental effect on growth performance.

Regarding the feeding value of sago in the second experiment, the higher body weight gain of birds fed sago basal diets during the 28-day grow out period was due to the high feed intake of this basal diet (Table 8). The improvement in body weight gain of birds fed sago basal diets resulted in the increase in carcass recovery (Table 8). This result indicated that sago basal diets were more palatable compared to maize-soybean basal diets. The result was in agreement with Nalle et al. (2017), who showed that the body weight gain and feed intake of birds fed on diets containing sago (0 to $200 \mathrm{~g} / \mathrm{kg}$ ) were higher compared to the control diets.

The enhancement of feed intake in the group of birds fed sago basal diets was probably due to a number of factors such as the color, texture, and flavor of the sago basal diets. According to Ferket \& Gernat (2006), feed recognition in poultry includes its appearance; this is particularly for the younger birds which have a preference for certain colors of feed (orange, blue, and green). In the present study, the color of sago particles is reddish (Figure 10); thus, when it is mixed with other feed ingredients and then pelleted, it will result in a brighter color of the pellet and crumble. Regarding the textural characteristics, sago texture was observed to be softer than the texture of maize. In addition, the distribution of sago particles was more homogenous, and the amount of fine particles of sago was less than the fine particles of maize. Ferket \& Gernat (2006) explained that feed consumption in the birds is perceived via mechanoreceptors, thermoreceptors, and chemoreceptors in the mouth. Mechanoreceptors help the birds quickly recognize the quality of feedthrough textural properties.

The addition of synbiotics Probio FM plus $^{\text {did }}$ not increase the carcass percentage of broilers. The result was in agreement with Helda et al. (2019) who reported that the supplementation of Probio FMplus (liquid and powder) did not improve the carcass percentage. AbdelHafeez et al. (2017) also proved that the addition of synbiotics did not increase the carcass percentage of broilers which were offered ad libitum or restricted diet.

The addition of synbiotics Probio FM plus $\mathrm{did}$ not show any improvement in growth performance and carcass recovery. The low body weight gain of birds fed diets supplemented with synbiotics Probio FM ${ }^{\text {plus }}$ was an unexpected result. This could be due to the low feed intake of broilers in this treatment (Table 8). The result of the present experiment did not agree with Helda et al. (2019) and Brugaletta et al. (2020). The difference was probably due to the methodology implemented. In the present study, synbiotics Probio FMplus was given to the birds only for 8 hours every day during the experimental period, while Helda et al. (2019) offered the synbiotics Probio FMplus for 24 hours. Brugaletta et al. (2020) used a different type of synbiotics (a microencapsulated synbiotics) included into their experimental diets, not through drinking water. In addition, the diets used in the present study were self-mixing diets. On the other hand, Helda et al. (2019) offered a commercial diet to the birds, which might contain other feed additives that could contribute to the performance of birds.

Based on the results of the present study, it was proven that sago (putak meal) has the potential to be used as a feed ingredient in poultry feed due to its high starch content, digestibility, and palatability. From an economic point of view, the price of sago (putak meal) is cheaper (IDR 2,000 per $\mathrm{kg}$, local distributor price) than the price of corn grain (IDR 3,750 per kg during the harvest season; IDR 4,500 per $\mathrm{kg}$ after the harvest season, local distributor price).

From a practical point of view, it seems that the process of producing sago (putak meal) from the pith of gebang tree was time and energy consuming. The pith of gebang tree needs to be chopped into a smaller size before being grounded with the typical grinder used in the present study. However, a more sophisticated grinding machine has been designed and produced in West Timor, Indonesia. The thick bark of the gebang tree no longer needs to be separated from the stem, and the pith of the tree does not need to be chopped before being grounded with this new type of grinder. This grinder also has three screen layers to separate sago from the undigested and hard fiber components. So, manual screening is no longer needed. Therefore, the time and energy used in sago processing have decreased which has led to the decrease in the price of sago (putak meal) as well as the price of complete feed containing sago (putak meal).

Further studies are needed to evaluate the maximum inclusion level of sago in broiler diets and the ap- 
plication of feed processing technology in sago-based diets. The ratio between amylase and amylopectin in starch, as well as the properties of the protein, lipid, and phosphate, should be further evaluated in order to examine their relationship with starch digestibility. The proportion of each fiber fraction is needed to be evaluated in order to apply the appropriate fiber degrading enzymes in the diets.

\section{CONCLUSION}

It is clearly shown in this study that the chemical composition, apparent metabolizable energy, and starch digestibility of sago obtained from the gebang tree are affected by their differing origins. The performance of birds fed sago diets was better than those broilers fed non-sago basal diets.

\section{CONFLICT OF INTEREST}

We certify that there is no conflict of interest with any financial, personal, or other relationships with other people or organization related to the material discussed in the manuscript.

\section{ACKNOWLEDGEMENT}

The authors would like to thank the Indonesian Ministry of Research, Technology and Higher Education that has provided funding for this research (Fundamental Research Scheme with Contract Number: 158/SP2H/LT/DRPM/2019). The valuable assistance of Steven Grant and Christine Flynn is fully appreciated.

\section{REFERENCES}

Abdel-Hafeez, H. M., E. S. E. Saleh, S. S. Tawfeek, I. M. I. Youssef, \& A. S. A. Abdel-Daim. 2017. Effects of probiotic, prebiotic, and synbiotic with and without feed restriction on performance, hematological indices and carcass characteristics of broiler chickens. Asian-Australas. J. Anim. Sci. 30:672-682. https://doi.org/10.5713/ajas.16.0535

Ai, Y. \& Jai-lin Jane. 2016. Macronutrients in corn and human nutrition. Comp. Rev. Food Sci. Food Safety. 15:581-598. https://doi.org/10.1111/1541-4337.12192

Alqaisi, O., O. S. Ndambi, \& R. B. Williams. 2017. Time series livestock diet optimization: cost-effective broiler feed substitution using the commodity price spread approach. Agric. Econ. 5:25.https://doi.org/10.1186/s40100-017-0094-9

Amerah, A. M. 2015. Interaction between wheat characteristics and feed enzyme supplementation in broiler diets. Anim. Feed Sci. Tech. 199:1-9. https://doi.org/10.1016/j. anifeedsci.2014.09.012

AOAC. 2005. Official Methods of Analysis of AOAC International. 18th ed. Gaithersburg, MD.

Ayres, V. E., J. N. Broomhead, X. Li, R. M. Raab, \& J. S. Moritz. 2019. Viscosity and growth response of broilers fed high fiber diets supplemented with a corn-produced recombinant carbohydrase. Appl. Poult. Res. 28:826-836 https:// doi.org/10.3382/japr/pfz039

Azhar, R., S. P. Rose, A. M. Mackenzie, S. C. Mansbridge, M. R. Bedford, A. Lovegrove, \& V. R. Pirgozliev. 2019. Wheat sample affects growth performance and the apparent metabolisable energy value for broiler chickens. British Poult.
Sci. 60:457-466. http://doi.org/10.1080/00071668.2019.16051 52

Ball, M. E. E., B. Owens, \& K. J. Mc Cracken. 2013. Chemical and Physical Predictors of the Nutritive Value of Wheat in Broiler Diets. Asian-Aust. J. Anim. Sci. 26: 97-107. https:// doi.org/10.5713/ajas.2012.12178

Bao, Y. M., L.F. Romero, \& A. J. Cowieson. 2013. Functional patterns of exogenouos enzymes in different feed ingredients. World's Poult. Sci. J. 69:759-774. https://doi.org/10.1017/ S0043933913000792

Bryden, W. L. \& X Li. 2010. Amino acid digestibility and poultry feed formulation: expression, limitations and application. R. Bras. Zootec. 39:279-287. https://doi.org/10.1590/ S1516-35982010001300031

Brugaletta, G., A. De Cesare, M. Zampiga, L. Laghi , C. Oliveri, C. Zhu, G. Manfreda , B. Syed , L. Valenzuela, \& F. Sirri. 2020. Effects of alternative administration programs of a synbiotic supplement on broiler performance, foot pad dermatitis, caecal microbiota, and blood metabolites. Anim. 10:522. http://doi.org./10.3390/ani10030522

Bulyaba, R., D. M. Winham, A. W. Lenssen, K. J. Moore, J. D. Kelly, M. A. Brick, E. M. Wright, \& J. B. Ogg. 2020 Genotype by location effects on yield and seed nutrient composition of common bean. Agronomy. 10: 347. https:// doi.org/10.3390/agronomy10030347

Choct, M., R. J. Hughes, \& G. Annison. 1999. Apparent metabolisable energy and chemical composition of Australian wheat in relation to environmental factors. Aust. J. Agric. Res. 50:447-451. https://doi.org/10.1071/A98155

Cho, M., M. N. Smit, L. He, F. C. Kopmels, \& E. Beltranena. 2019. Effect of feeding zero- or high-tannin Faba bean cultivars and dehulling on growth performance, carcass traits and yield of saleable cuts of broiler chickens. J. Appl. Poult. Res. 0:1-19. https://doi.org/10.3382/japr/pfz099

Eagleton, G. E. 2016. Review: Persisten pioneers; Borasus L. and Corypa L.in Malesia. Biodeversitas. 17:716-732. https://doi. org/10.13057/biodiv/d170247

Ferket, P. R. \& A. G. Gemat. 2006. Factors that affect feed intake of meat birds: a review. Int. J. Poult. Sci. 5:905-911. https:// doi.org/10.3923/ijps.2006.905.911

Gomez, K. A. \& A. A. Gomez. 1984. Statistical Procedure for Agricultural Research. $2^{\text {nd }}$ ed. John Wiley \& Sons, New York.

Haug, W. \& Hans-Joachim Lantzsch. 1983. Sensitive method for the rapid determination of phytate in cereals and cereals products. J. Sci. Food Agric. 34:1423-1426. https://doi. org/10.1002/jsfa.2740341217

Helda, A.Y. Ninu, \& C. L. Nalle. 2019. The supplementation effect of Probio FMplus as synbiotic in liquid and solid formson the broiler carcass quality. Eco. Env. \& Cons. 25: S25-S30.

Hill, F. W. \& D. L. Anderson. 1958. Comparison of metabolizable energy and productive energy determinations with growing chicks. J. Nutr. 64:587-603. https://doi.org/10.1093/ jn/64.4.587

Karunaratne N. D., D. A. Abbott, P. J. Hucl, R. N. Chibbar, C. J. Pozniak, \& H. L. Classen. 2018. Starch digestibility and apparent metabolizable energy of western Canadian wheat market classes in broiler chickens. Poult. Sci. 97:2818-2828. https://doi.org/10.3382/ps/pey115

Kidd, M. T. \& P. B. Tilman. 2016. Key principles concerning dietary amino acid responses in broilers. Anim. Feed Sci. Tech. 221:314-322. https://doi.org/10.1016/j. anifeedsci.2016.05.012

Kim, D. O., S. W. Jeong \& C. Y. Lee. 2003. Antioxidant capacity of phenolic phytochemicals from various cultivars of plums. Food Chem. 81:321-326. https://doi.org/10.1016/ S0308-8146(02)00423-5 
Lee, J., D. S. Nam, \& C. Kong. 2016. Variability in nutrient composition of cereal grains from different origin. Springer plus. 5:419. https://doi.org/10.1186/s40064-016-2046-3

Makkar, H. P. S. 2003. Quantification of Tannins in Tree And Shrub Foliage. A Laboratory Manual. Joint FAO/IAEA, Division of Nuclear Techniques in Food and Agriculture. Kluwer Academic Publishers, Dordrecht, The Netherlands. https://doi.org/10.1007/978-94-017-0273-7

Mateos, G. G., E. Jimenez-Moreno, M. P. Serrano, \& R. P. Lazaro. 2012. Poultry response to high levels of dietary fiber sources varying in physical and chemical characteristics. J. Appl. Poult. Res. 21 :156-174. https://doi.org/10.3382/ japr.2011-00477

McDonald, P., R. A. Edwards. J. F. D. Greenhalgh, \& C. A. Morgan. 2002. Animal Nutrition. $6^{\text {th }}$ ed. Prentice Hall, United Kingdom.

Mtei, A. W., M. R. Abdollahi, N. Schreurs, C. K. Girish, and V. Ravindran. 2019. Dietary inclusion of fibrous ingredients and bird type influence apparent ileal digestibility of nutrients and energy utilization. Poult. Sci. 98:6702-6712. https://doi.org/10.3382/ps/pez383

Naiola, B. P. \& N. Nurhidayaf. 2009. Biology of gewang (Corypha utan Lamarck) seeds: embryo content diversity, chemical content and the roles of microbes in seed germination. Berita Biologi. 9:773-781.

Nalle, C. L., V. Ravindran, \& G. Ravindran. 2010. Nutritional value of faba beans (Vicia faba L.) for broilers: Apparent metabolisable energy, ileal amino acid digestibility and production performance. Anim. Feed Sci. Tech. 156:104111. https://doi.org/10.1016/j.anifeedsci.2010.01.010

Nalle, C. L., V. Ravindran, \& G. Ravindran. 2011. Nutritional value of narrow-leafed Lupin (Lupinus angustifolius) for Broilers. British Poult. Sci. 52:775-81. https://doi.org/10.10 80/00071668.2011.639343

Nalle, C. L., V. Ravindran, \& G. Ravindran. 2012. Nutritional value of white Lupins (Lupinus albus) for broilers: Apparent metabolisable energy, apparent ileal amino acid digestibility and production performance. Animal: an International Journal of Animal Bioscience 6:579-85. http://doi.org/ 10.1017/S1751731111001686

Nalle, C. L., M. R. K. Yowi, \& D. R. Tulle. 2017. Nutritional value of putak: apparent metabolisable energy and growth performance. Int. J. Agr. Sys. 5:53-59. https://doi. org/10.20956/ijas.v5i1.1170

Nalle, C. L., A. H. Angi, M. A. J. Supit, \& S. Ambarwati. 2019a. Aflatoxin and Ochratoxin A contamination in maize grains and sago (putak meal) from different sources for poultry in West Timor, Indonesia. Int. J. Poult. Sci. 18:353-360. https://doi.org/10.3923/ijps.2019.353.360

Nalle, C. L. \& M. R. K. Yowi. 2019b. Nutritional value of fermented rice bran for broiler chickens: apparent metabolisable energy and growth performance. Int. J. Poult. Sci. 18:618-625. https://doi.org/10.3923/ijps.2019.618.625

Olukosi, O. A., R. L. Walker, \& J. G. M. Houdijk. 2019. Evaluation of the nutritive value of legume alternatives to soybean meal for broiler chickens. Poult. Sci. 98:5778-5788. https://doi.org/10.3382/ps/pez374

Ouyang K., M. Xu, Y. Jiang, \& W. Wang. 2016. Effects of alfalfa flavonoids on broiler performance, meat quality, and gene expression. Can. J. Anim. Sci. 96:331-340. https://doi. org/10.1139/cjas-2015-0132

Pei-yao, L., W. Jing Wang, W. Shu-geng, G. Jun, D. Yan, Z. Haijun, \& Q. Guang-Hai. 2020. Standardized ileal digestible amino acid and metabolizable energy content of wheat from different origins and the effect of exogenous xylanase on their determination in broilers. Poultry Sci. 99:992-1000. https://doi.org/10.1016/j.psj.2019.10.013

Prasetyo, K.W., Subyanto, \& B. P. Naiola. 2008. Physical and mechanical properties of gewang (Corypha utan Lamk) stem from East Nusa Tenggara. J. Trop. Wood. Sci. Tech. 6:1-6.

Raza, R., S. Bashir, \& R. Tabassum. 2019. An update on carbohydrases: growth performance and intestinal health of poultry. Heliyon. 5: e01437. https://doi.org/10.1016/j.heliyon.2019.e01437

Ravindran, V., O. Adeola, M. Rodehutscord, H. Kluth, J. D. van der Klis, E. van Eerden, \& A. Helmbrecht. 2017. Determination of ileal digestibility of amino acids in raw materials for broiler chickens - Results of collaborative studies and assay recommendations. Anim. Feed Sci. Tech. 225:62-72. https://doi.org/10.1016/j.anifeedsci.2017.01.006

Rohollah, E., J. B. Liang, M. F. Jahromi, P. Shokryazdan, M. Ebrahimi, W. Li Chen, \& Y. M. Goh. 2015. Effects of tannic acid on performance and fatty acid composition of breast muscle in broiler chickens under heat stress. Italian J. Anim. Sci. 14:4. https://doi.org/10.4081/ijas.2015.3956

SAS Institute. SAS/STAT® User's Guide: Statistics. (University Edition). SAS Institute Inc., Cary, NC, USA.

Sharif, S. D., F. Shariatmadari, \& A. R. Yaghobfar. 2012. Effects of inclusion of hull-less barley and enzyme supplementation on broiler diets on growth performance, nutrient digestion and dietary metabolizable energy content. J. Cent. Europ. Agr. 13:193-207. https://doi.org/10.5513/ JCEA01/13.1.1035

Slominsky, B. A. 2011. Recent advances in research on enzymes for poultry diets. Poultry Science $90: 2013-2023$. http://doi. org/ 10.3382/ps.2011-01372

Smeets, N., F. Nuyens, L. Van Campenhout, E. Delezie, J. Pannecoucque, \& T. Niewold. 2015. Relationship between wheat characteristics and nutrient digestibility in broilers: comparison between total collection and marker (titanium dioxide) technique. Poult Sci. 94:1584-91. https://doi. org/10.3382/ps/pev116

Smeets, N., F. Nuyens, L. Van Campenhout, E. Delezie, \& T. A. Niewold. 2018. Interactions between the concentration of non-starch polysaccharides in wheat and the addition of an enzyme mixture in a broiler digestibility and performance trial. Pout. Sci. 97:2064-2070. https://doi. org/10.3382/ps/pey038

Spring, P. 2013. The challenge of cost effective poultry and animal nutrition: Optimizing existing and applying novel concepts. Lohmann Info. Vol. 48:38.

Indonesian National Standard (SNI-01-2891). 1992. How to test food and beverages. Indonesian National Standard Agency. pp. 18-20. [Indonesian].

Svihus, B. 2014. Starch digestion capacity of poultry. Poult. Sci. 93:2394-2399. https://doi.org/10.3382/ps.2014-03905

Swain, B. K., P. K. Naik, \& N. P. Singh. 2014. Unconventional feed resources for efficient poultry production. Tech. Bulletin. No. 47.

Tahir, M., A. B. Batal, \& G. M. Pesti. 2015. Broiler response model to estimate the economic importance of dietary feed enzymes. J. Appl. Poult. Res. 24:37-48. https://doi. org/10.3382/japr/pfv004

Tomaszewska, E., S. Muszyński, P. Dobrowolski, M. Kwiecień , R. Klebaniuk, S. Szymańczyk, A. Tomczyk, S. Kowalik, A. Milczarek, \& I. Świetlicka. 2015. The influence of dietary replacement of soybean meal with high-tannin faba beans on gut-bone axis and metabolic response in broiler chickens. Ann. Anim. Sci. 18: 801-824. https://doi. org/10.2478/aoas-2018-0019

Truong H. H., K. A. Neilson, B. V. McInerney, A. Khoddami, T. H. Roberts, S. Y. Liu, \& P. H. Selle. 2015. Performance of broiler chickens offered nutritionally-equivalent diets based on two red grain sorghums with quantified kafirin concentrations as intact pellets or re-ground mash following steam-pelleting at 65 or $97^{\circ} \mathrm{C}$ conditioning 
temperatures. Anim. Nut. 1:220-228. https://doi. org/10.1016/j.aninu.2015.08.002

Wealleans A. L., W. Li, L. F. Romero, G. Mathis, \& B. Lumpkins. 2017. Performance and cost-benefit improvements following supplementation with a combination of direct-fed microbials and enzymes to broiler chickens raised with or without ionophores. J. Appl. Poult. Res. 27:23-32. https:// doi.org/10.3382/japr/pfx036

Woyengo, T. A. \& C. M. Nyachoti. 2013. Review: Antinutritional effects of phytic acid in diets for pigs and poultry-current knowledge and directions for future research. Can. J. Anim. Sci. 93:9-21. https://doi.org/10.4141/ cjas2012-017
Yacout, M. H. M. 2015. Anti-nutritional factors \& its roles in animal nutrition. J. Dairy Vet. Anim. Res. 4:237-239. https:// doi.org/10.15406/jdvar.2016.04.00107

Yaghobfar, A. \& Kalantar, M. 2017. Effect of non-starch polysaccharide (NSP) of wheat and barley supplemented with exogenous enzyme blend on growth performance, gut microbial, pancreatic enzyme activities, expression of glucose transporter (SGLT1) and mucin producer (MUC2) genes of broiler chickens. Brazilian J. Poult. Sci. 19:629-638. https:// doi.org/10.1590/1806-9061-2016-0441 